\section{Four more years ${ }^{1}$}

\author{
George A. O. Alleyne
}

1 Presented 23 September 1998 in Washington, D.C., at the 25th Session of the Pan American Sanitary Conference, where the Member Governments reelected Dr. Alleyne to a four-year term as Director.
First, let me thank you Ministers and Heads of Delegations for the manner in which you received my nomination and for having placed your trust in me by electing me yet again to be the Director of the Pan American Sanitary Bureau and to be nominated as Regional Director of the World Health Organization for the Americas. You have thereby given me an opportunity that is given to few-to be of service to the people of the Americas through this unique common venture of ours represented by the Pan American Health Organization. You have conferred upon me a signal honor and in so doing honored my country and the Region that was the crucible for what I am.

I can never tire of thanking you for these past four years as your Director. They have been rich in experience, and I have stored in the most safe and sacred place hundreds of memories in which many of you have shared.

There have been interviews with your presidents and prime ministers. There have been discussions in your countries about the nature of our cooperation and the ways in which it might serve you better. There have been many occasions of pomp and ceremony. Nevertheless, there is nothing more precious to me than the recollection of those occasions when we have witnessed together simple activities in the places where your people, my people, live and love and labor and die. I will always recall the small children of Tacuarembó in Uruguay; the proud people of Pocrí in Panama; the women of Chiclayo in Peru, who built silos to protect their harvest grains from rats that brought them the plague; the tenement yard in Trench Town, Jamaica, where Bob Marley cooked his cornmeal porridge. I could go on and on. These were the places where I could hear and see and feel the various ways health was being improved, and our Organization is proud to be a part of your efforts.

I look forward to many more such experiences, but they will have to be confined to these next four years. As much as I love what we do and have no other aim but to see the Pan American Health Organization continue to flourish, I will not stand before you in this role again.

However, let me erase immediately any misconceptions that these next four years will be only ones of consolidating the status quo. There is much to be done and many new ways of cooperation to be explored. 
We will try to ensure that these four years represent a proper culmination of 100 years of work by PAHO. We will reach our centenary in 2002, and I wish it to be a celebration of what has been done in the Americas in health with the support of PAHO. It will be 100 years we have walked together, and I wish us to recall the successes as well as learn from the setbacks we have encountered along the way. During this period we must also be thinking of the changes and refinements that will make our Organization last and be useful to its constituencies for another hundred years.

"Let me erase immediately any misconceptions that these next four years will be only ones of consolidating the status quo. There is much to be done and many new ways of cooperation to be explored."

I had been concerned that this period leading up to the end of the century and into a new millennium might have brought to our Organization the attitudes and perceptions characterized as the fin de siècle syndrome. Ends of centuries have tended to be marked or marred by general malaise, despair, and decadence as reflected in art, literature, and sometimes public practice. My fear was that those most pernicious aspects of it that could be spread rapidly by our facile communications might have tainted our countries, their health sectors, and our Organization. Fortunately, we have not experienced this syndrome. I wish to depict our Organization today as one that has reformulated its mission, rethought its technical cooperation as I promised four years ago, and is composed in the main of men and women who, as I have quoted before, "wish to build clocks and not only tell the time."

The next four years will bring changes in our external environment to which we must respond and adapt. Our existence and success for the last 96 years is a manifestation of our capacity for response and adaptation.

There is every indication that our Region will continue to see its population grow, and the growth is likely to be greatest among the marginalized and dispossessed. We will undoubtedly face the threats of new diseases and the fear that old ones may return to haunt us. We must address the health aspects of the graying of our population and the increased dependency of the elderly upon the de- clining proportion of those who are young. We view with apprehension the racial and ethnic conflicts in various parts of the globe and hope that this contagion does not involve us on a grand scale. We will struggle to establish and maintain policies that preserve and protect our environment, always and ever maintaining the anthropocentric view. We will be caught up in the revolution of information and agonize over whether the phenomenon of interconnectedness will disconnect us from those human interactions that, in fundamental ways, characterize and define us as persons. We know that our economies will have to survive the perils of globalization; most of us feel powerless before that mighty juggernaut as we watch our States restructure and reform themselves.

Health must not be a victim of this restructuring and reform. We must take on some of the responsibility for focusing the necessary political attention on protecting those health services that are indeed essential public goods. But perhaps our most urgent and immediate need may be to examine how we as an Organization must position ourselves to deal with that economic miasma that seems to be creeping all over the world. Financial instability and insecurity threaten to wipe out decades of work and sacrifice by millions of our citizens. In the 1980s we examined how the crisis had affected us. Shall we again agonize after the fact and seek to repair the damage done by a restructuring and reform that seemed to care nothing for health?

But I confess that the scenario that still concerns me most is related to the growing gaps between people. From what I have heard in the last four years, and especially in the last two days, you are equally concerned. It is that gap that led me four years ago to state without equivocation or reservation that one of the fundamental principles that would underlie my administration would be the search for more equity in health-that those gaps that are unnecessary and unjust should be closed.

"There will have to be equity in the
prevention of illness and the promotion
of health."

The passage of time has not shaken my adherence to this value. However, I have understood much better the nature of the task to be undertaken to make this ideal more relevant. I know better that 
equity does not mean more poor services for the poor. I understand more clearly that there will have to be equity in the prevention of illness and the promotion of health. I am more conscious of the need to act on the assumption that the inequities in the determinants of health are the root cause of those unjust inequalities in health outcomes. I am clearer as to the role of health authorities and of PAHO in this search, and I am pleased that there is more than a groundswell of opinion as to the correctness of this concern, particularly here in the Americas where the breach is widest.

The President of Brazil, Fernando Henrique Cardoso, wrote of humanizing growth through equity and said:

So we face a paradox: the demand for equity is on the increase, partly as a result of the globalization of information, yet is directed to a state that is reducing its functions and has less control over its economic policy options.

This demand for equity - a key concept in the transition from the imperatives of economic efficiency to the realm of social action-is not new.

And then in what could be seen as an appeal to us here at this meeting, he said:

The biggest challenge for multilateral organizations is to reinvent the sense of community and to give room for international solidarity.

This solidarity, this ability for small and large, for rich and poor, to work together for health is a precious thing. My wife tells me that tears almost came to her eyes when she saw Jamaican and Argentine football teams stand together this past summer at the World Cup in France. They were there as competitors, but they were sharing in a larger experience. And I wish to see this joint contribution to a larger experience made even more patent in our Pan-American approach to health in the Region. We will continue to try-and with your help I am confident that we can succeed.

Yes, we will have specific goals for health, but this is not the place to spell them out, as the details have been elaborated in the Strategic and Programmatic Orientations that you have adopted for PAHO. However, there are some needs that can almost be translated into specific calls to arms.

We will, for example, commit to preventing an additional 25000 infant deaths every year for the next four years. We will recommit to maintaining our Region free of poliomyelitis. By the year 2002 we will consign the rash of measles to the pictures that should be only of historical interest to new generations of health workers. No man, woman, or child receiving a blood transfusion must be infected with Trypanosoma cruzi, HIV, hepatitis, or syphilis. There will be ever-increasing attention paid to those often-forgotten people with mental health problems. Finally, fewer of our citizens must smoke.

As a basis for all of this, we will recommit ever more firmly to emphasizing in all our work the linchpin role that information plays in the chain of data, information, knowledge, and wisdom. We will continue to strive towards having the culture of production and use of information firmly woven into the fabric of our work.

As I promised four years ago, I have extended our hand to a wide range of agencies, institutions, and organizations that share our values and our concern for health. But this is not enough. We must more aggressively espouse the cause of health, but not for the sake of burnishing the image of PAHO. Instead, I believe we must seek a place for health not in the corridors of power, but at the tables of power. The extent to which countries, agencies, and organizations work with us is a reflection of the trust and respect our Organization has built up over its history. In the next four years, we will seek even more innovative ways to project the image of our collective work and make our various publics aware of it.

"We must more aggressively espouse the
cause of health. We must seek a place for
health not in the corridors of power, but at
the tables of power."

I wish to see us work with all our major partners to establish a common agenda for health in the Americas by the year 2000. Simple as it sounds, this will be a major and audacious task. But if you accept the challenge it will be possible to engage those persons and agencies in the Americas whose activities touch on health to agree to a basic framework into which the many pieces can fit.

I will maintain the fiscal and programmatic transparency which you have every right to demand, and I will ensure that PAHO has the offices and instruments to safeguard that transparency. The guardianship of the resources we receive from you is a sacred trust. My record over the past four years is such that I do not have to refer to the need for gender diversity in this Organization. 
I will involve our staff in my planning to streamline our practices and make those changes in the Secretariat of PAHO that are necessary to ensure that it is even more responsive to your needs. Some of these changes will involve incorporating new disciplines into the Organization to deal with the new health challenges we face.

We are ever conscious of our dependence on your commitment to supporting PAHO morally and financially. I am proud of the manner in which you, our Member States, support the Organization. I trust that over the years this assistance will continue and increase so that PAHO is not hobbled by the small but painful cuts that if continued would eventually erode what you have constructed over the past 96 years.

I have been proud to be the Director of the Pan American Sanitary Bureau and simultaneously
Regional Director of the World Health Organization, and I would not wish otherwise. My experience has convinced me that this arrangement brings value and luster to both Organizations. You have my assurance that I will do everything in my power to see that we do not put asunder what has been joined together in a productive relationship over 50 years-a relationship that has benefited the people of the Americas and the world.

Distinguished delegates, I wish much for health in the Americas. Sometimes because of that fervor, I speak with a passion that is inappropriate for my public persona. I cannot hide it. I cannot help it. But I take comfort in the words of the philosopher Hegel: "Nothing great in the world has ever been achieved without passion."

I thank you again and hope I can prove to be worthy of your trust. 